\title{
EVALUATION OF THE THERMAL RESISTANCE OF SELECTED BENTONITE BINDERS
}

\author{
OCENA TOPLOTNE UPORNOSTI IZBRANIH BENTONITNIH \\ VEZIV
}

\author{
Jaroslav Beňo $^{1}$, Jiřina Vontorová ${ }^{2}$, Vlastimil Matějka ${ }^{3}$, Karel Gál ${ }^{1}$ \\ ${ }^{1}$ Department of Metallurgy and Foundry Engineering, Faculty of Metallurgy and Material Engineering, VŠB-Technical University of Ostrava, \\ 17. listopadu 15/2172, 70833 Ostrava - Poruba, Czech Republic \\ 2Department of Chemistry, Faculty of Metallurgy and Material Engineering, VŠB-Technical University of Ostrava, 17. listopadu 15/2172, \\ 70833 Ostrava - Poruba, Czech Republic \\ ${ }^{3}$ Nanotechnology Centre, VŠB-Technical University of Ostrava, 17. listopadu 15/2172, 70833 Ostrava - Poruba, Czech Republic \\ jaroslav.beno@vsb.cz
}

Prejem rokopisa - received: 2014-07-29; sprejem za objavo - accepted for publication: 2014-09-03

doi:10.17222/mit.2014.126

\begin{abstract}
Bentonite is one of the most widely used clays associated with various applications. In the case of foundry technology, bentonite is primarily used as a binder for the mold manufacture. The thermal resistance of bentonite binders, also called the thermal stability, is a natural property of clay minerals, depending on the source, the mineralogical and chemical composition of clay and it is also closely connected to the bentonite structure (various interlayer ions, the level of ion substitution of montmorillonite). Generally, there are various methods for evaluating this property. This contribution describes various methods of determining the bentonite thermal stability based on the evaluation of the technological parameters of bentonite molding mixtures and their comparison. These methods were chosen on the basis of a background research and practical experiences. For the experiments the bentonites commonly used in the foundries of the Czech and Slovak region were selected.

Keywords: bentonites, clay minerals, thermal stability, dehydration, dehydroxylation
\end{abstract}

Bentonit je ena najpogosteje uporabljanih glin, povezanih z različno uporabo. V livarstvu se bentonit uporablja predvsem kot vezivo pri izdelavi form. Toplotno upornost bentonitnih veziv imenujemo tudi toplotna stabilnost in je naravna lastnost mineralov glin, odvisna je od izvora, mineraloške in kemijske sestave gline in je tudi tesno povezana s strukturo bentonita (različni ioni med plastmi, nivo nadomestila ionov v montmorilonitu). Obstaja več metod za oceno te lastnosti. Ta prispevek opisuje različne metode določanja toplotne stabilnosti bentonita, ki temeljijo na oceni tehnoloških parametrov bentonitnih mešanic za forme in njihovo primerjavo. Te metode so bile izbrane na podlagi raziskav ozadja in praktičnih izkušenj. Za preizkuse so bili izbrani bentoniti, ki se uporabljajo v livarnah na Čškem in Slovaškem.

Ključne besede: bentoniti, minerali glin, toplotna stabilnost, dehidracija, dehidroksilacija

\section{INTRODUCTION}

Bentonite as a natural and abundant soil is being widely used in a large range of industrial applications. A high CEC, the swelling ability and a high surface area of bentonite predetermine it for utilization in ceramics, cosmetics, nanocomposites, environmental protection, waste-water treatment, nuclear-waste deposits or manufacture of foundry molds and cores. ${ }^{1-6}$

As a rule, bentonites consist of the montmorillonite clay with the amount of the montmorillonite mineral higher than mass fractions $w=70 \%$ to $75 \%$, which means that it contains up to $30 \%$ of other minerals, above all aluminosilicates and also micas and carbonates. Individual bentonite localities also differ with their genesis. In principle, the bentonites do not differ in the chemical composition, but their behaviors are quite different (because of their mineral composition, physical characteristics, etc.). Nowadays the required properties are achieved by mixing the bentonites from different localities

The thermostability of bentonite is connected with the temperature of the clay dehydroxylation, i.e., with liberating the $\mathrm{OH}^{-}$groups from the octahedral network in the form of $\mathrm{H}_{2} \mathrm{O}(\mathrm{g})$. The residual oxygen remains in the structure. At the same time the binding properties are gradually lost and the "burnt-out bentonite" is formed. The whole process is endothermic and it can be well monitored with a thermal analysis (DTA). The thermostability and its testing methods were studied by Jelínek et al. ${ }^{7}$ In the bentonites of a mean quality the endothermic reactions are present in the temperature region from $450{ }^{\circ} \mathrm{C}$ to $550{ }^{\circ} \mathrm{C}$. The bentonites with a high thermostability (a loss of crystallic water, dehydroxylation, occurs in the range from $700{ }^{\circ} \mathrm{C}$ up to $750{ }^{\circ} \mathrm{C}$ ) often even have two peaks, at $500{ }^{\circ} \mathrm{C}$ and $700{ }^{\circ} \mathrm{C}$. This state is explained as follows:

- a substitution of ions in montmorillonite octahedrons and tetrahedrons (the influence of $\mathrm{Fe})^{8}$

- defects in the lattice (vacancies)

- a difference in the size of montmorillonite particles ${ }^{9}$.

The influence of $\mathrm{Fe}$ on dehydroxylation has not yet been unambiguously explained. A low concentration of $\mathrm{Fe}(<8 \%)^{7}$ results in a low dehydroxylation temperature; Fe-rich bentonites have higher dehydroxylation 
temperatures ${ }^{10}$. On the contrary, Grefhorst ${ }^{11}$ and Kaplun ${ }^{12}$ give an opinion that with the increasing $\mathrm{Fe}_{2} \mathrm{O}_{3}$ content the dehydroxylation temperature is falling (in the range of $2-14 \%$ ) and in the presence of black coal the fall is even more intense.

Due to the thermal exposure of the mold buildup of bentonite during metal casting, the amount of the active bentonite decreases and the non-reactive (burnt-out) bentonite is formed. For each cycle of the mold preparation the used mixture is reactivated with an addition of fresh bentonite in order to maintain the portion of active bentonite (replacing the burnt-out bentonite in the sand). The burnt-out bentonite amount of the foundry sand is affected by the thermal stability of bentonite. The thermal stability of bentonite is usually determined as the temperature of dehydroxylation or, more precisely, the temperature of the crystal-lattice destruction and/or the measure of the loss of its plasticity.

The objectives of this study are: i) an evaluation of the basic physical and chemical properties of the bentonites from the Czech and Slovak region commonly used in the foundry industry, and a comparison of the parameters of these bentonites with natural $\mathrm{Na}^{+}-$the bentonite of the Wyoming type; ii) an evaluation of the impact of the bentonite chemical composition on its thermal stability with respect to its utilization in the foundry industry (with an emphasis on $\mathrm{Fe}$ and $\mathrm{Mg}$ contents); iii) a determination of the thermal stability of bentonite samples evaluated with the methods based on an evaluation of the technological parameters of the bentonite molding mixtures; iv) a comparison of individual methods and an assessment of the optimum method for determining the bentonite thermal stability.

\section{MATERIALS AND METHODS}

Four commonly used binders supplied as soda-activated foundry bentonites and one natural sodium bentonite of the Wyoming type were used for the experiments within this research.

The studied bentonites comprise the following groups of bentonites: i) two bentonites mined and produced in the Czech Republic (assigned as $\mathrm{Sa}$ and $\mathrm{K}$, from the West Bohemian region), ii) two bentonites from the Central Slovakia region, assigned as B and S; and iii) a natural sodium bentonite of the Wyoming type (USA), assigned as P, was used as the standard material.

The following general parameters (Table 1) commonly used for the characterization of bentonites were determined: a) the moisture under the temperature of 105 ${ }^{\circ} \mathrm{C}$ up to the constant weight; b) $\mathrm{pH}$ and conductivity of water suspension (a $1: 10$ solid-liquid ratio); c) the loss of ignition (LOI) of dried samples $\left(105^{\circ} \mathrm{C}\right.$ up to the constant weight) at $900{ }^{\circ} \mathrm{C} / 2 \mathrm{~h}$.

The chemical compositions of the studied samples were determined using energy dispersive fluorescence spectrometer (XRFS) SPECTRO XEPOS (SPECTRO
Analytical Instruments $\mathrm{GmbH}$ ) equipped with a $50 \mathrm{~W}$ Pd $\mathrm{X}$-ray tube. The samples for the analysis were prepared in the form of pressed tablets (wax was used as a binder) for this measurement.

The thermal stabilities of the selected bentonite samples were determined as the ratio of the values of the selected technological properties (splitting strength, wet tensile strength, determination of the methylene-blue consumption - an active clay test) before and after the annealing of the bentonite molding mixture.

The samples of the bentonite molding mixture were prepared with a 5 min homogenization of the mixture of the studied bentonite with silica sand, in the constant weight ratio of $8: 100$ and with an appropriate amount of water ensuring a constant compactibility of (45 \pm 3$) \%$ using an MK 00 sand mill. The prepared mixtures were processed into standard cylinders $(\varnothing 50$, a height of 50 $\mathrm{mm}$ ) to obtain the samples for the determination of the technological parameters.

The splitting strengths were measured using a WADAP testing machine of the LRU-1 type, while the wet tensile strength was measured using a +GF+ testing machine of the SPNF type.

\section{RESULTS AND DISCUSSION}

The basic bentonite-binder parameters are summarized in Table 1. The natural moisture of the samples determined at $105^{\circ} \mathrm{C}$ (as the loss of weight) varied a lot, ranging from $6.93 \%(\mathrm{~K})$ to $11.69 \%$ (standard $-\mathrm{P}$ ). The conductivity of the elements prepared from the studied bentonites varies significantly in the range from 457 $\mu \mathrm{S} / \mathrm{cm}$ to $2800 \mu \mathrm{S} / \mathrm{cm}$, measured for samples $\mathrm{P}$ and $\mathrm{S}$, respectively. The lowest conductivity as well as the lowest $\mathrm{pH}$ value obtained for bentonite $\mathrm{P}$ are connected with the fact that bentonite $\mathrm{P}$ is a natural bentonite (not activated by soda).

Table 1: Basic parameters of the studied bentonite samples Tabela 1: Osnovni parametri preiskanih vzorcev bentonita

\begin{tabular}{|c|c|c|c|c|}
\hline \multirow{2}{*}{ Sample } & moisture & $\mathrm{pH}$ & conductivity & LOI \\
\cline { 2 - 5 } & $w / \%$ & $(-)$ & $\mu \mathrm{S} / \mathrm{cm}$ & $w / \%$ \\
\hline $\mathrm{Sa}$ & 7.16 & 10.27 & 1422 & 16.30 \\
\hline $\mathrm{K}$ & 6.93 & 10.16 & 1067 & 13.60 \\
\hline $\mathrm{B}$ & 8.21 & 10.43 & 1456 & 12.60 \\
\hline $\mathrm{S}$ & 10.46 & 10.50 & 2800 & 16.30 \\
\hline $\mathrm{P}$ & 11.69 & 9.54 & 457 & 12.20 \\
\hline
\end{tabular}

The values of the loss of weight at the ignition (up to $900{ }^{\circ} \mathrm{C}$ ) of individual samples ranged from 12.20 (P) up to $16.30 \%(\mathrm{Sa})$. The LOI values reached the values typical for the amount of water present in the interlayer space of montmorillonite (approximately $w=12 \%$ ).

The chemical compositions of the studied samples were evaluated with XRFS, whereas the amounts of the analyzed elements were recalculated to the amounts of oxides and resumed in Table 2. The most important 
elements associated with the bentonite-binder behavior under high temperatures (mainly $\mathrm{Fe}$ and $\mathrm{Mg}$ ) were selected.

Table 2: Technological parameters of the basic salt-core mixtures Tabela 2: Tehnološki parametri osnovnih slanih mešanic za jedra

\begin{tabular}{|c|c|c|c|c|c|}
\hline $\begin{array}{c}\text { Composition } \\
(w / \%) / B \text { Bentonite }\end{array}$ & $\mathrm{Sa}$ & $\mathrm{K}$ & $\mathrm{B}$ & $\mathrm{S}$ & $\mathrm{P}$ \\
\hline $\mathrm{Na}_{2} \mathrm{O}$ & 2.00 & $<1.00$ & 2.50 & 3.05 & $<1.00$ \\
\hline $\mathrm{Al}_{2} \mathrm{O}_{3}$ & 11.80 & 15.80 & 16.40 & 17.16 & 16.70 \\
\hline $\mathrm{SiO}_{2}$ & 44.30 & 53.90 & 60.20 & 59.01 & 59.10 \\
\hline $\mathrm{CaO}$ & 4.69 & 2.40 & 1.49 & 1.34 & 1.22 \\
\hline $\mathrm{MgO}$ & 3.20 & 2.50 & 2.20 & 1.72 & 2.20 \\
\hline $\mathrm{Fe}_{2} \mathrm{O}_{3}$ & 12.88 & 8.50 & 2.16 & 1.77 & 4.31 \\
\hline
\end{tabular}

Although sample $\mathrm{K}$ should be rich in the $\mathrm{Na}^{+}$content (the sample is a soda-activated bentonite), the chemical analysis performed with XRFS showed the amount of $\mathrm{Na}_{2} \mathrm{O}$ to be bellow the detection limit; the same situation was observed for bentonite $\mathrm{P}$ activated without soda.

The lowest amount of $\mathrm{Na}_{2} \mathrm{O}$, measured for samples $\mathrm{K}$ and $\mathrm{P}$, is in good agreement with the measured conductivity of their water suspensions (Table 1).

From the background research, mentioned above, it is evident, that the thermal resistance of bentonite binders to higher temperatures is closely connected to the $\mathrm{Mg}$ and $\mathrm{Fe}$ contents. According to the chemical analysis of the studied samples there is no significant difference between the $\mathrm{Mg}$ contents of the bentonite samples.

The $\mathrm{Mg}$ content ranged from $1.72 \%$ (sample $\mathrm{S}$ ) up to $3.20 \%$ (sample Sa). On the other hand, the Fe content differs significantly. The highest value of the Fe content was obtained for sample Sa (12.88\%), while the lowest value of the Fe content was detected for sample $\mathrm{S}$ $(1.77 \%)$. On the basis of the results of the XRFS analysis, it can be assumed that the highest thermal resistance will be obtained for samples S, B or P.

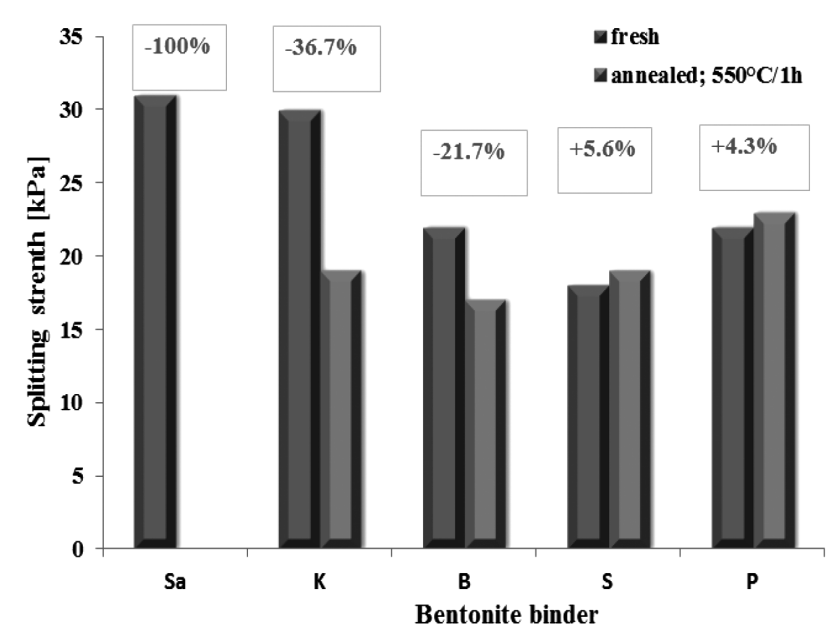

Figure 1: Thermal stability of the bentonites determined as the ratio of splitting strengths

Slika 1: Toplotna stabilnost bentonita, določena kot razmerje trdnosti pri cepljenju
For the determination of the thermal stability of the studied bentonite samples two methods were selected. The first procedure includes a determination of the thermal stability as the ratio of the mechanical properties of the fresh and annealed molding mixtures. The temperature of the thermal exposition of $550{ }^{\circ} \mathrm{C} / 1 \mathrm{~h}$ was selected on the basis of the background research. ${ }^{6-12}$

The values of the splitting strength of the bentonite molding mixture with individual bentonite samples are summarized in Figure 1.

The evaluated values of the technological parameters significantly depend on the type of a bentonite sample as evident from Figures $\mathbf{1}$ and $\mathbf{2}$.

The optimum mechanical properties required for molds (high values of the splitting strength in the fresh state) were obtained for all the samples, but the highest values were found for sample $\mathrm{Sa}(31 \mathrm{kPa})$ and $\mathrm{K}$ $(30 \mathrm{kPa})$, respectively.

However, the lowest thermal resistance, calculated as the ratio of the splitting strengths of the fresh and annealed bentonite molding mixtures was detected for bentonite $\mathrm{Sa}$ (a $100 \%$ decrease in the splitting-strength values).

From this point of view, even though sample $\mathrm{Sa}$ in its fresh state suggested the best mechanical properties, the highest thermal stability was obtained for samples $\mathrm{P}$ and $\mathrm{S}$, where no change was found.

A slight increase in the splitting-strength values detected for samples $\mathrm{S}(+5.6 \%)$ and $\mathrm{P}(+4.3 \%)$ was probably caused by a measurement error.

Generally, a more sensitive parameter for the evaluation of the bentonite-binder quality is the determination of the wet tensile strength of the bentonite molding mixture. The results of these experiments are summarized in Figure 2.

All the samples suggest satisfactory values of the wet tensile strength. In practice there is a rule, according to which the value of the wet tensile strength should be

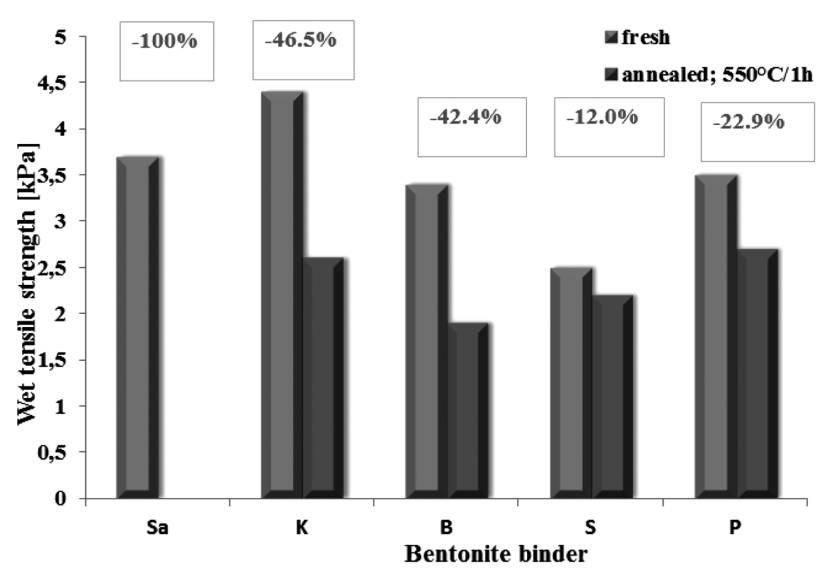

Figure 2: Thermal stability of bentonites determined as the ratio of wet tensile strengths

Slika 2: Toplotna stabilnost bentonitov, določena kot razmerje natezne trdnosti v vlažnem 
higher than $2.0 \mathrm{kPa}$. In these experiments it ranges from $2.5 \mathrm{kPa}(\mathrm{S})$ to $4.4 \mathrm{kPa}(\mathrm{K})$. After the annealing the values of the wet tensile strength significantly decreased for all the bentonite samples.

The highest decrease was also detected for sample Sa $(-100.0 \%)$. The lowest decrease in the wet tensile strength was obtained for samples S $(-12.0 \%)$ and $\mathrm{P}$ $(-22.9 \%)$.

The second method of determining the bentonite thermal stability includes a preparation of two molding mixtures. The first mixture was prepared with $5 \%$ dried bentonite and the second with $5 \%$ annealed bentonite.

Then active-clay tests (a determination of the methylene-blue consumption) were carried out. The thermal stability was calculated as the ratio of the bentonite molding mixtures with fresh (dried, $105{ }^{\circ} \mathrm{C}$ ) and annealed bentonites.

The results of these experiments are summarized in Figure 3.

The results of these experiments (the determination of active bentonite) suggested the same trend as the previous experiments based on the determination of the mechanical properties of the molding mixtures with individual bentonite samples.

The minimum (the lowest) thermal stability was also found for sample $\mathrm{Sa}(-53.8 \%)$ and the maximum thermal stability was found for sample P $(-8.5 \%)$.

Finally, all the most important parameters based on the results of the thermal-stability determination for the individual bentonite samples are summarized in Table 3.

Table 3: Resume of the thermal stability of the studied bentonite samples

Tabela 3: Pregled toplotnih stabilnosti preiskovanih bentonitnih vzorcev

\begin{tabular}{|c|c|c|c|c|c|c|}
\hline Parameter & onite & $\mathrm{Sa}$ & $\mathrm{K}$ & B & $\mathrm{S}$ & $\mathrm{P}$ \\
\hline$\Delta S T S$ & \multirow{5}{*}{$(\%)$} & -100.0 & -36.7 & -21.7 & +5.6 & +4.3 \\
\hline$\Delta W T S$ & & -100.0 & -46.5 & 42.4 & -12.0 & -22.9 \\
\hline$\triangle A B T$ & & -53.8 & -18.2 & 29.5 & -18.4 & -8.5 \\
\hline $\mathrm{MgO}$ & & 3.20 & 2.50 & 2.20 & 1.72 & 2.20 \\
\hline $\mathrm{Fe}_{2} \mathrm{O}_{3}$ & & 12.88 & 8.50 & 2.16 & 1.77 & 4.31 \\
\hline
\end{tabular}

Note: $\triangle S T S$ - change in the splitting strength

$\triangle W T S$ - change in the wet tensile strength

$\triangle A B T$ - change in the active-bentonite test

The experiments carried out in order to evaluate the thermal stability of the selected bentonite binders commonly applied at the Czech and Slovak foundries show that, in all the cases, the lowest thermal resistance was observed for sample $\mathrm{Sa}$. It is probably related to the highest amount of Fe $(12.88 \%)$. This fact is in line with our previous research?

Even if sample $\mathrm{P}$ is natural sodium bentonite (not soda activated) this sample shows the highest thermal stability. It also shows the minimum decrease in the mechanical properties and methylene-blue consumption applied for the evaluation of the thermal stability. It is in good accordance with the theory of clay binders.,

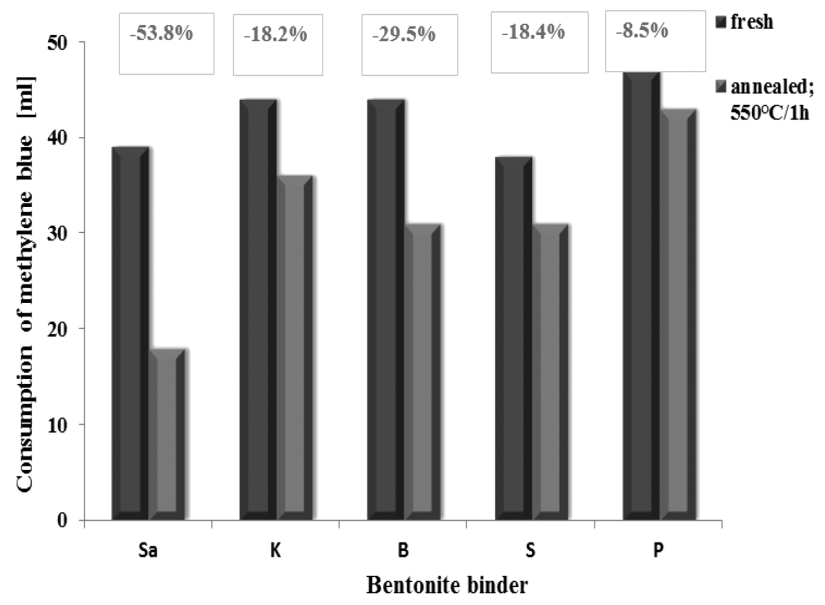

Figure 3: Thermal stability of bentonites determined as the ratio of the methylene-blue tests

Slika 3: Toplotna stabilnost bentonitov, določena kot razmerje preizkusov metilen modro

\section{CONCLUSION}

Thermal stability, the natural property of clay minerals, depends on the source, the mineralogical and chemical composition of clay and, thus, it is always necessary to evaluate the suitability of a given clay for a selected purpose.

The results obtained within this work clearly show the influence of the Fe amount on the thermal stability of bentonites as the highest thermal stability was observed for bentonite $\mathrm{P}$ which also shows almost the lowest iron amount. A high amount of iron was observed for sample Sa which demonstrates the lowest thermal resistance.

The optimum method for assessing the thermal stability of the bentonite binder appears to be the method based on a different methylene-blue consumption of the bentonite molding mixture with fresh and annealed bentonite. This method eliminates the potential problems with the preparation of a molding mixture and the natural loss of water (drying) from the mixture during the experiments, which can negatively affect the results of the measurements. This method is also more sensitive and more conclusive with respect to the evaluation of the thermal resistance of a bentonite binder.

\section{Acknowledgement}

The research was carried out within the frame of internal projects of the VŠB-Technical University of Ostrava, SP2014/61 and SP2014/62.

\section{REFERENCES}

${ }^{1}$ C. Paluskiewicz, M. Holtzer, A. Bobrowski, FTIR analysis of bentonite in moulding sands, Journal of Molecular Structure, 880 (2008) 1-3, 109-114, doi:10.1016/j.molstruc.2008.01.028 


\section{J. BEŇO et al.: EVALUATION OF THE THERMAL RESISTANCE OF SELECTED BENTONITE BINDERS}

${ }^{2}$ V. J. Inglezakis et al., Removal of $\mathrm{Pb}(\mathrm{II})$ from aqueous solutions by using clinoptilolite and bentonite as adsorbents, Desalination, 210 (2007) 1-3, 248-256, doi:10.1016/j.desal.2006.05.049

${ }^{3}$ H. A. Patel et al., Preparation and characterization of phosphonium montmorillonite with enhanced thermal stability, Applied Clay Science, 35 (2007) 3-4, 194-200, doi:10.1016/j.clay.2006.09.012

${ }^{4} \mathrm{~J}$. Madejova et al., Behaviour of $\mathrm{Li}+$ and $\mathrm{Cu} 2+$ in heated montmorillonite: Evidence from far-, mid-, and near-IR regions, Vibrational Spectroscopy, 40 (2006) 1, 80-88, doi:10.1016/j.vibspec. 2005.07.004

${ }^{5}$ F. Mikšovský, P. Lichý, The oolitization rate determination of bentonite moulding mixtures, Archives of Foundry Engineering, 8 (2008) 2, 103-106

${ }^{6}$ I. Vasková, J. Malik, P. Futáš, Tests of moulding mixture by using various clay binder granularity, Archives of Foundry Engineering, 9 (2009) 1, 29-32
${ }^{7}$ P. Jelinek et al., Thermostability of montmorillonitic clays, China Foundry, 11 (2014) 3, 201-207

${ }^{8}$ L. Heller et al., An approximation of the position of some cations in dehydroxylated montmorillonite, Clay Minerals Bulletin, 4 (1961) 25, 213-220

${ }^{9}$ R. Gauglitz, H. E. Schwiete, Thermochemical investigations on montmorillonite with regards to type, grain size, and cation loading, Berichte Deutsche Keramik Ges, 38 (1964), 43-49

${ }^{10} \mathrm{P}$. Wu, C. Ming, The relationship between acidic activation and microstructural changes in montmorillonite from Heping, China, Spectrochimica Acta A, 63 (2006) 1, 85-90, doi:10.1016/j.saa.2005. 04.050

${ }^{11}$ C. Grefhorst, Investigation of bentonites, Giesserei, 93 (2006) 5, 26-31

${ }^{12}$ V. I. Kaplun et al., New studies of Čerkas bentonite, Litějnoje proizvodstvo, 6 (2006), 12-15 